\title{
Presence of simian virus 40 in diffuse large B-cell lymphomas in Tunisia correlates with germinal center B-cell immunophenotype, $\mathbf{t}(14 ; 18)$ translocation, and P53 accumulation
}

\author{
Khaled Amara ${ }^{1}$, Mounir Trimeche ${ }^{1}$, Sonia Ziadi ${ }^{1}$, Adnene Laatiri ${ }^{2}$, Sarra Mestiri ${ }^{1}$, \\ Badreddine Sriha ${ }^{1}$, Moncef Mokni ${ }^{1}$ and Sadok Korbi ${ }^{1}$ \\ ${ }^{1}$ Department of Pathology, CHU Farhat Hached, Sousse, Tunisia and ${ }^{2}$ Department of Clinical Hematology, \\ CHU Farhat Hached, Sousse, Tunisia
}

\begin{abstract}
Previously we have reported the presence of simian virus 40 DNA in $56 \%$ of diffuse large B-cell lymphomas in Tunisia. Here, we investigated the relationship between the status of simian virus 40 and $t(14 ; 18)$ translocation, germinal center status, and P53 and BCL2 expression to assess the clinical and biological relevance of simian virus 40 presence in diffuse large B-cell lymphomas. Therefore, we evaluated by immunohistochemistry the expression patterns of CD10, BCL6, MUM1, BCL2, and P53 in 86 diffuse large B-cell lymphomas (48 simian virus 40-positive and 38 simian virus 40 -negative cases). The $t(14 ; 18)$ translocation was investigated by polymerase chain reaction. Immunostaining patterns for CD10, BCL6, and MUM1 were used to subclassify diffuse large B-cell lymphoma cases as germinal center or non-germinal center phenotypes. Germinal center phenotype, $t(14 ; 18)$, P53, and BCL2 expression were found in $71,30,55$, and $65 \%$ of cases, respectively. Interestingly, germinal center phenotype, $t(14 ; 18)$, and P53 accumulation were found to be more frequent in simian virus 40-positive cases than in simian virus 40 -negative ones $(81,44,69$ vs $58,13,37 \% ; P=0.018,0.002$, and 0.003 , respectively). However, there were no correlations between the presence of simian virus 40 and the expression of CD10, BCL6, MUM1 and BCL2, patient's age and gender, clinical stage, or the International Prognosis Index. Multivariate logistic regression analyses revealed that the germinal center phenotype, P53 accumulation, and $t(14 ; 18)$ were independent factors for simian virus 40 association $(P=0.029,0.006$, and 0.014 , respectively). There were no significant differences in overall survival regarding P53, BCL2, or $t(14 ; 18)$ status. However, patients with germinal center phenotype or low International Prognosis Index scores displayed a significantly better survival than those with non-germinal center phenotype or high International Prognosis Index scores $(P=0.003$ and 0.0001 , respectively). These two prognosis factors remain independent in multivariate analyses $(P=0.001$ and $<0.0001$, respectively). Interestingly, among patients with germinal center phenotype, simian virus 40-positive subgroup displayed a significantly shorter survival than simian virus 40 -negative subgroup $(P=0.034)$. In summary, these findings support a role of simian virus 40 in the pathogenesis of diffuse large B-cell lymphomas. On other hand, they suggest that a significant proportion of diffuse large B-cell lymphoma cases with germinal center phenotype may result from early transformation by simian virus 40 , mainly those harboring the $t(14 ; 18)$.

Modern Pathology (2008) 21, 282-296; doi:10.1038/modpathol.3800993; published online 28 December 2007
\end{abstract}

Keywords: diffuse large B-cell lymphomas; germinal center immunophenotype; $t(14 ; 18)$; P53; simian virus 40; Tunisia

Diffuse large B-cell lymphomas represent the most common category of non-Hodgkin's lymphomas and are characterized by heterogeneous biological,

Correspondence: Dr M Trimeche, MD, PhD, Department of Pathology, CHU Farhat Hached, Sousse 4000, Tunisia.

E-mail: m_trimech@yahoo.fr

Received 27 September 2007; revised 7 November 2007; accepted 15 November 2007; published online 28 December 2007 clinical, immunophenotypic, and genetic features. ${ }^{1,2}$ They constitute approximately $30-40 \%$ of all nonHodgkin's lymphomas diagnosed in Western countries, ${ }^{1,3,4}$ and account for an even higher proportion in developing countries, with approximately $50 \%$ non-Hodgkin's lymphomas in Tunisia. ${ }^{5}$

Recent advances in gene expression profiling using microarray technology have identified at least two subgroups in diffuse large B-cell lymphomas, 
known as germinal center B-cell-like and activated B-cell-like with different clinical outcomes. Moreover, it has been shown recently that conventional immunohistochemistry could give similar results concerning prognosis using protein expression patterns of a small number of selected markers. ${ }^{6-9}$ The identification of these two subgroups has increased interest in defining more specific markers for each group. On the other hand, BCL2/JH gene rearrangements, as known by $\mathrm{t}(14 ; 18)$ translocation, is detectable in up to one-third of cases of diffuse large B-cell lymphomas, mainly in germinal center diffuse large B-cell lymphoma group. ${ }^{10}$

Like in other cancers, tumorigenesis in diffuse large B-cell lymphomas involves multiple factors. P53 is a major tumor suppressor gene, which was shown to be affected in a wide range of human cancers, including hematological malignancies. ${ }^{11}$ Mutations of the P53 gene often lead to the accumulation of the mutated protein in the nucleus of neoplastic cells. However, several investigators have demonstrated that a large fraction of nonHodgkin's lymphomas, especially diffuse large B-cell lymphomas, accumulates the wild-type P53 at the nuclear level, ${ }^{11-15}$ suggesting the existence of other alternative mechanisms responsible for its stabilization, such as binding of P53 protein to viral oncoproteins. ${ }^{16,17}$ Previous reports, however, have failed to demonstrate any correlation between P53 accumulation in diffuse large B-cell lymphomas and several oncogenic viruses, including Epstein-Barr virus. ${ }^{18-20}$

Several studies from the United States, ${ }^{21-23}$ Japan, ${ }^{24}$ Costa Rica, ${ }^{25}$ and Taiwan ${ }^{26}$ have successfully detected simian virus 40 (SV40) DNA by PCRbased methods in variable proportions of nonHodgkin's lymphomas, mainly diffuse large B-cell lymphomas, ranging from 11 to $62 \%$ of cases. We have recently ${ }^{27}$ reported a high prevalence of SV40 in diffuse large B-cell lymphomas occurring in Tunisian patients $(56 \%)$, and we noted that the presence of SV40 was significantly correlated with aberrant promoter hypermethylation of several tumor suppressor genes, suggesting a functional effect of this virus in those lymphomas. The oncogenic potential of SV40 is thought to be through its primary viral gene product, large $\mathrm{T}$ antigen, viral oncoprotein responsible for SV40 replication and SV40-mediated cell transformation. ${ }^{28}$ In vitro experiments have shown that SV40 large T antigens promote transformation by binding and inactivating the products of several tumor suppressor genes, particularly P53. ${ }^{28,29}$ Despite these suggestions of a possible link between SV40 and P53 accumulation, no previous studies have investigated the potential implication of the SV40 in such accumulation of P53 protein in diffuse large B-cell lymphomas.

In this study, we tried to determine the prevalence of the germinal center phenotype, the $t(14 ; 18)$ translocation, and P53 accumulation, and their relationship with SV40 in diffuse large B-cell lymphomas in Tunisia. Furthermore, we evaluated the prognostic value of each above parameters according to the SV40 status in those lymphomas. Therefore, we have investigated 86 diffuse large B-cell lymphomas (48 SV40-positive and 38 SV40negative cases) using immunohistochemistry to study the expression of CD10, BCL6, MUM1, BCL2, and P53 and PCR for the detection of the $\mathrm{t}(14 ; 18)$.

\section{Materials and methods}

\section{Patients and Tissue Samples}

This study was based on 86 cases of diffuse large B-cell lymphoma with well-characterized SV40 status on the basis of PCR assays (48 SV40-positive and 38 SV40-negative cases). Those cases were selected from a large series of diffuse large B-cell lymphomas previously reported ${ }^{27}$ on the basis of the availability of sufficient paraffin-embedded tumor biopsy specimens for further analysis. All samples investigated in this study were clinical cases routinely examined between 1995 and 2005 and diagnosed at the Department of Pathology at the Farhat Hached Hospital of Sousse (Tunisia). The clinicopathological characteristics of patients are presented in Table 1. Clinical follow-up information was available for 46 patients. The median fellow-up time of patients was 15 months (range: 0-96 months). The end point of clinical follow-up was either the date of the last contact or the date of death until May 2007. The International Prognostic Index was also evaluated for those patients. Thirty-three had low International Prognosis Index scores $(\leq 2$; low-risk and low-intermediate-risk groups) and the remaining 13 patients had high International Prognosis Index scores ( $>2$; high-intermediate-risk and high-risk groups). No significant relationships were found between the status of SV40 and tumor location, patient's age and gender, or overall survival (Table 1).

\section{Classification of Tumors into Germinal and Non-Germinal Center Subgroups}

Cases were subclassified into germinal center or non-germinal center subgroup based on the immunoexpression profile of CD10, BCL6, and MUM1 according to the decision-tree proposed by Hans et $a l^{6}$ (Figure 1). The germinal center subgroup includes all CD10 + cases and those with a CD10-/BCL6 + /MUM1 - immunophenotype. Other immunophenotypes are assigned to the second group, the so-called non-germinal center, which includes $\mathrm{MUM} 1+$ tumors regardless of their BCL6 status (CD10-/BCL6 + /MUM1 + or CD10-/ BCL6-/MUM1 +). Cases expressing none of these three markers are also classified as non-germinal center diffuse large B-cell lymphomas. 
Immunohistochemical analyses were performed on formalin-fixed, paraffin-embedded tissue sections using monoclonal antibodies directed against CD10, BCL6, and MUM1 as described previously. ${ }^{30}$

Table 1 Clinical characteristics of SV40-positive and SV40negative diffuse large B-cell lymphoma cases included in this study

\begin{tabular}{|c|c|c|c|c|}
\hline & $\begin{array}{l}\text { Total } \\
\text { number of } \\
\text { cases }\end{array}$ & $\begin{array}{l}\text { Number of } \\
\text { SV40-positive } \\
\text { cases }\end{array}$ & $\begin{array}{c}\text { Number of } \\
\text { SV40-negative } \\
\text { cases }\end{array}$ & $\mathrm{P}$-value \\
\hline \multicolumn{5}{|l|}{ Gender } \\
\hline Male & 48 & 30 & 18 & 0.161 \\
\hline Female & 38 & 18 & 20 & \\
\hline \multicolumn{5}{|c|}{ Tumor location } \\
\hline Nodal & 60 & 33 & 27 & 0.817 \\
\hline Extranodal & 26 & 15 & 11 & \\
\hline \multicolumn{5}{|l|}{ Age (years) } \\
\hline $\begin{array}{l}\text { Median } \\
\text { (range) }\end{array}$ & & $61(3-85)$ & $63(18-81)$ & 0.545 \\
\hline$\leq 60$ & 44 & 24 & 20 & 0.808 \\
\hline$>60$ & 42 & 24 & 18 & \\
\hline \multicolumn{5}{|c|}{ Lactate dehydrogenase level ${ }^{\mathrm{a}}$} \\
\hline Normal & 7 & 3 & 4 & 0.258 \\
\hline Elevated & 39 & 25 & 14 & \\
\hline \multicolumn{5}{|c|}{ WHO performance status ${ }^{\mathrm{a}}$} \\
\hline$\leq 1$ & 26 & 15 & 11 & 0.615 \\
\hline$>1$ & 20 & 13 & 7 & \\
\hline \multicolumn{5}{|l|}{ B symptoms ${ }^{\mathrm{a}}$} \\
\hline Absent & 34 & 21 & 13 & 0.548 \\
\hline Present & 12 & 7 & 5 & \\
\hline \multicolumn{5}{|c|}{ Ann arbor stage ${ }^{\mathrm{a}}$} \\
\hline I/II & 20 & 11 & 9 & 0.474 \\
\hline III/IV & 26 & 17 & 9 & \\
\hline \multicolumn{5}{|c|}{ Extranodal sites involvment ${ }^{\mathrm{a}}$} \\
\hline$\leq 1$ & 39 & 25 & 14 & 0.258 \\
\hline$>1$ & 7 & 3 & 4 & 0.232 \\
\hline \multicolumn{5}{|c|}{ International Prognosis Index risk group ${ }^{\mathrm{a}}$} \\
\hline Low (0-2) & 33 & 18 & 15 & \\
\hline High (3-5) & 13 & 10 & 3 & \\
\hline \multicolumn{5}{|c|}{ Overall survival (years) ${ }^{\mathrm{a}}$} \\
\hline $\begin{array}{l}\text { Median } \\
\text { (range) }\end{array}$ & & $15.5(0-70)$ & $14.5(1-96)$ & 0.813 \\
\hline
\end{tabular}

${ }^{\mathrm{a}}$ Data available for 46 patients.
Briefly, 5 - $\mu \mathrm{m}$-thick paraffin-embedded tissue sections were cut and dried overnight at $56^{\circ} \mathrm{C}$, deparaffinized, and rehydrated. Antigen retrieval was performed with the appropriate buffer (Table 2) by boiling sections in a water bath for 20 min until the temperature reached $98^{\circ} \mathrm{C}$, and endogenous peroxidase activity was blocked with hydrogen peroxide/ methanol for $5 \mathrm{~min}$. Sections were then incubated with the appropriate primary monoclonal antibody (Table 2). Immunostaining was performed using the EnVision + system (Dako, Glostrup, Denmark) according to the manufacturer's instructions, and immunoreactivity was visualized with the 3,3diaminobenzidine. Sections were counterstained with Mayer's hematoxylin, permanently mounted, and viewed with a standard light microscope. For each experiment, positive and negative controls were included; for negative controls, the primary antibody was omitted and replaced with phosphatebuffered saline, and for positive controls, tonsils with reactive lymphoid hyperplasia were used as an external control tissue. All immunohistochemically stained slides were evaluated independently by two pathologists. For CD10, BCL6, and MUM1, cases were considered positive if $20 \%$ or more of the tumor cells were immunoreactive. For BCL6 and MUM1, only diffuse or granular nuclear staining was considered positive. For CD10, only membrane staining was considered positive.

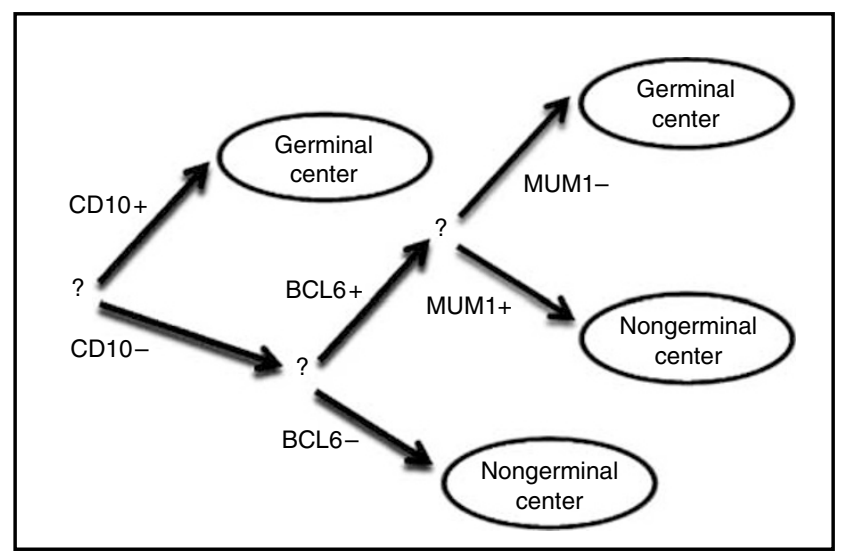

Figure 1 Schematic illustration of the subgrouping strategy applied for the immunophenotypic classification of diffuse large B-cell lymphomas in germinal center and non-germinal center groups as proposed by Hans et al. ${ }^{6}$

Table 2 Detailed list of the antibodies used for immunohistochemistry analysis in this study

\begin{tabular}{|c|c|c|c|c|}
\hline Antibody & Clone & Source & Antigen retrieval & Dilution \\
\hline CD10 & $56 \mathrm{C} 6$ & NeoMarkers & Citrate buffer (10 mM, pH 9.0) & $1: 50$ \\
\hline BCL6 & PG-B6p & Dako & EDTA buffer (1 mM, pH 8.0) & $1: 25$ \\
\hline MUM1 & MUM1p & Dako & Citrate buffer (10 mM, pH 9.0) & $1: 50$ \\
\hline BCL2 & 124 & Dako & Citrate buffer (10 mM, pH 6.0) & $1: 50$ \\
\hline P53 & DO-7 & Dako & Citrate buffer (10 mM, pH 6.0) & $1: 50$ \\
\hline
\end{tabular}




\section{P53 and BCL2 Immunohistochemical Analyses}

Immunohistochemical staining for P53 and BCL2 expression was carried out on formalin-fixed paraffin-embedded tissue sections from all cases as described above using monoclonal antibodies listed in Table 2. P53 protein expression was considered positive if nuclear staining was observed in $10 \%$ or more of the tumor cells. ${ }^{31}$ For BCL2 expression, cases were scored as positive if $50 \%$ or more of the tumor cells showed cytoplasmic staining. ${ }^{32}$

\section{BCL2/JH Gene Rearrangements Detection by PCR}

Genomic DNA was extracted from 5 - $\mu$ m-thick paraffin-embedded tissue sections using proteinase $K$ $(200 \mu \mathrm{g} / \mathrm{ml})$ digestion as described previously. ${ }^{33}$ Detection of the BCL2/JH gene rearrangements involving the major breakpoint region (MBR), the intermediate cluster region (ICR), or the minor cluster region (MCR) of the BCL2 gene was performed as described previously. ${ }^{34-36}$ PCR assays were performed in a $25 \mu$ l reaction volume containing $400 \mathrm{ng}$ DNA template, $20 \mathrm{pmol}$ each primer, $1 \mathrm{U}$ GoTaq DNA polymerase (Promega, Madison, WI, USA), $2 \mathrm{mM} \mathrm{MgCl}_{2}$, and $200 \mu \mathrm{M}$ each dNTP. The optimized PCR conditions were $10 \mathrm{~min}$ at $93^{\circ} \mathrm{C}$ for initial denaturation, then 35 cycles of $1 \mathrm{~min}$ of denaturation at $93^{\circ} \mathrm{C}, 1 \mathrm{~min}$ of annealing following a gradient in annealing temperatures from 55 to $60^{\circ} \mathrm{C}$ for MBR, from 58 to $62^{\circ} \mathrm{C}$ for ICR, and from 59 to $61^{\circ} \mathrm{C}$ for MCR, and $1 \mathrm{~min}$ of extension at $72^{\circ} \mathrm{C}$. After 35 cycles, the samples were incubated for a final extension step at $72{ }^{\circ} \mathrm{C}$ for $10 \mathrm{~min}$ to complete the reaction. The size of the products ranged from 80 to $300 \mathrm{bp}$ for $\mathrm{MBR} / \mathrm{JH}$ and ICR/JH rearrangements, and from 500 to $550 \mathrm{bp}$ for MCR/JH rearrangements. The products were separated on $2 \%$ agarose gels containing ethidium bromide and visualized under ultraviolet illumination using Gel Doc 2000 System (Bio-Rad, Marnes-la-Coquette, France). In each experiment, controls (water as negative, and DNA extracted from follicular lymphoma cases carrying the $\mathrm{t}(14 ; 18)$ translocation as positive) were tested simultaneously. Standard precautions were taken to guard against PCR contamination.

\section{Statistical Analyses}

To determine the relationship between clinicopathological parameters as well as between the presence of SV40 and each of these parameters, $\chi^{2}$ or Fisher's exact tests were carried out. Overall survival (calculated from the date of diagnosis to death or last follow-up) was estimated using the KaplanMeier method. The equality between survival curves was tested with the log-rank test. The simultaneous relationship of multiple prognostic factors to survival was assessed using the Cox proportional hazards model. For all tests, a $P$-value less than 0.05 was regarded as significant. Statistical analyses were carried out with the SPSS software package for Windows, version 11.5.

\section{Results}

\section{Immunohistochemical Findings}

Results of the immunohistochemical staining for each antigen are shown in Figure 2 and Table 3. On the basis of the expression of CD10, BCL6, and MUM1 (as described in the Materials and methods section), 61 (71\%) and 25 (29\%) cases were assigned to germinal center and non-germinal center groups, respectively. In the germinal center group, 24 cases expressed only CD10, 19 cases expressed only BCL6, and 18 cases expressed both CD10 and BCL6. MUM1 expression was seen in $34 \%$ of the germinal center cases. In the non-germinal center group, 12 cases expressed only MUM1 and 13 cases expressed both MUM1 and BCL6. BCL2 expression was observed in $56(65 \%)$ of the 86 diffuse large B-cell lymphoma cases. P53 overexpression (nuclear accumulation in $10 \%$ or more of tumor cells) was observed in 47 $(55 \%)$ of the 86 diffuse large B-cell lymphoma cases. Comparative study of clinicopathological features between germinal center and non-germinal center diffuse large B-cell lymphoma groups is summarized in Table 4. There were no correlations between the germinal center status and patient's age, gender, tumor location, BCL2 or P53 status. Interestingly, germinal center phenotype was more frequently observed in SV40-positive cases than in SV40negative ones $(39 / 48 \quad(81 \%)$ vs $22 / 34 \quad(58 \%)$; $P=0.018$; Table 4). However, there was no correlation between the expression of CD10, BCL6, MUM1, or BCL2 markers and the SV40 status (Table 5). P53 accumulation was also more observed in SV40positive diffuse large B-cell lymphoma cases than in SV40-negative cases (33/48 (69\%) vs 14/38 (37\%); $P=0.003$; Table 5). However, there was no correlation between P53 accumulation and patient's age, gender, or tumor location (data not shown).

\section{Molecular Analyses for BCL2/JH Gene Rearrangements}

The $\mathrm{t}(14 ; 18)$ translocation was successfully detected in $26(30 \%)$ of the 86 diffuse large B-cell lymphoma cases (Figure 3). Nineteen cases and eight cases were positive by the PCR targeting the MBR and the ICR regions of the BCL2 gene, respectively. However, none of the cases showed the translocation at the MCR region. Figure 3 shows representative agarose gel electrophoresis of the PCR products. There was no significant relationship between the $\mathrm{t}(14 ; 18)$ translocation and germinal center status, tumor location, patient's age and gender, BCL2 expression or P53 accumulation (Table 6). However, the $\mathrm{t}(14 ; 18)$ translocation was more frequently found 

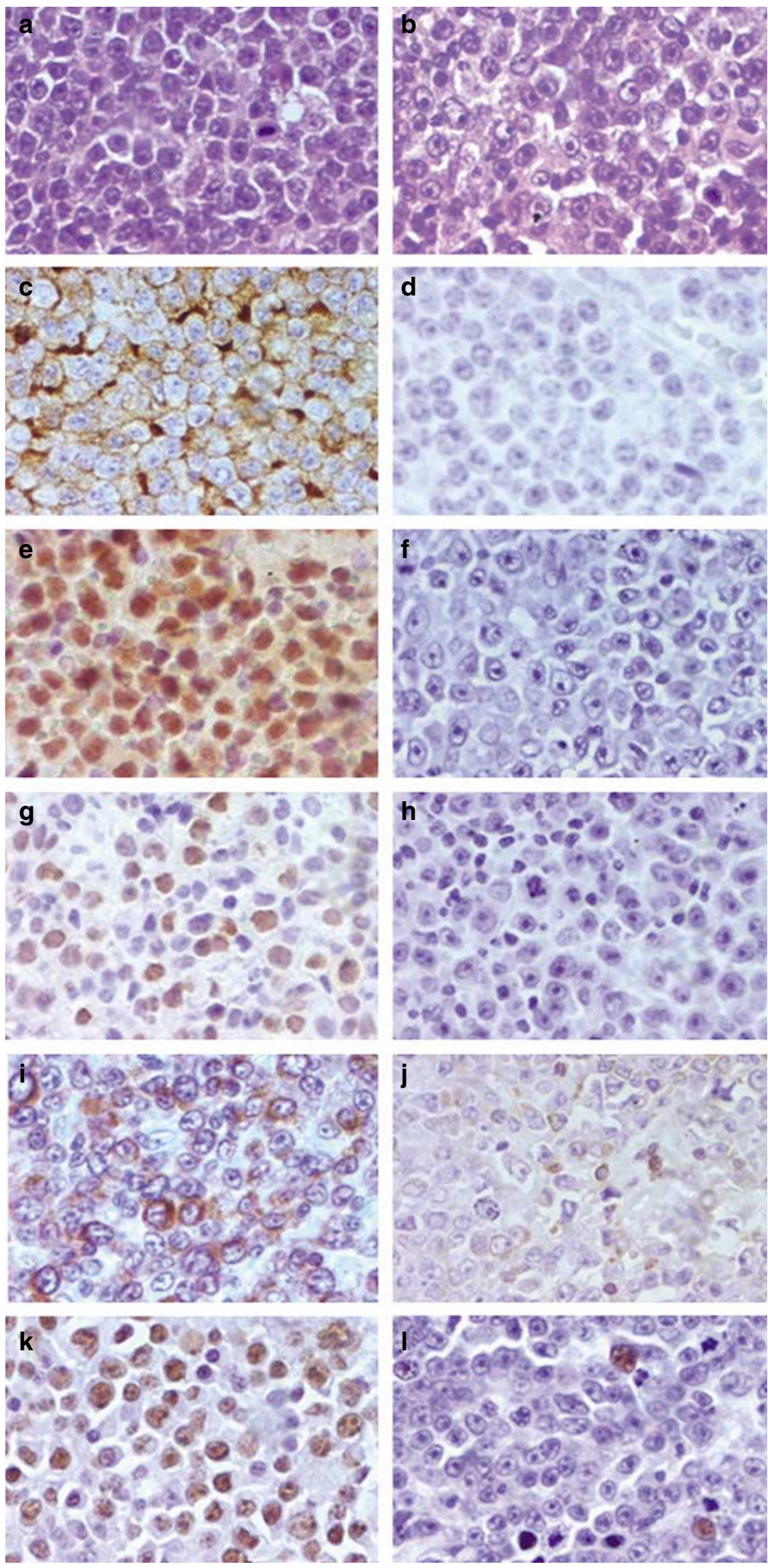

Figure 2 Representative hematoxylin-eosin and immunohistochemical staining in diffuse large B-cell lymphomas. (a and b) Typical histological patterns of diffuse large B-cell lymphomas (hematoxylin-eosin, $\times 400$ ). (c, e, g, i, and k) Examples of positive immunostaining for CD10, BCL6, MUM1, BCL2, and P53, respectively (immunohistochemistry, $\times 400)$. (d, f, h, j, and l) Examples of negative immunostaining for CD10, BCL6, MUM1, BCL2, and P53, respectively (immunohistochemistry, $\times$ 400). 
Table 3 Summary of immunohistochemical findings and the t(14;18) status in SV40-positive and SV40-negative diffuse large B-cell lymphoma cases

\begin{tabular}{|c|c|c|c|c|c|c|c|c|}
\hline \multirow[t]{2}{*}{ SV40 status } & \multirow[t]{2}{*}{ Case no. } & \multicolumn{5}{|c|}{ Immunohistochemistry } & \multirow[t]{2}{*}{ PCR BCL2/JH } & \multirow[t]{2}{*}{ Germinal center status } \\
\hline & & P53 & $B C L 2$ & $C D 10$ & $B C L 6$ & MUM1 & & \\
\hline \multirow[t]{48}{*}{ SV40-positive cases } & L65 & + & - & - & + & + & + & Non-GC \\
\hline & L104 & + & + & - & - & + & - & Non-GC \\
\hline & L88 & + & - & - & - & + & - & Non-GC \\
\hline & L58 & + & + & - & - & + & + & Non-GC \\
\hline & L67 & + & - & - & - & + & - & Non-GC \\
\hline & L87 & + & + & - & - & + & + & Non-GC \\
\hline & L101 & + & + & - & + & + & - & Non-GC \\
\hline & L80 & + & - & - & - & + & - & Non-GC \\
\hline & L56 & + & + & - & + & + & - & Non-GC \\
\hline & L76 & + & + & + & + & - & + & GC \\
\hline & L68 & + & + & + & + & + & + & GC \\
\hline & L55 & + & + & + & + & + & + & GC \\
\hline & L63 & + & - & + & + & - & - & GC \\
\hline & L103 & - & + & + & + & - & - & GC \\
\hline & L86 & + & + & + & + & + & - & GC \\
\hline & L62 & + & + & + & + & + & - & GC \\
\hline & L60 & - & + & + & - & + & + & GC \\
\hline & L46 & - & + & + & - & + & + & GC \\
\hline & L56 & - & - & + & - & - & + & GC \\
\hline & L93 & - & - & + & - & - & - & GC \\
\hline & L81 & - & + & + & - & + & - & GC \\
\hline & L53 & - & + & - & + & - & + & GC \\
\hline & L71 & + & - & - & + & - & + & GC \\
\hline & L57 & + & - & - & + & - & - & GC \\
\hline & L50 & + & - & - & + & - & - & GC \\
\hline & L75 & - & + & - & + & - & - & GC \\
\hline & L85 & + & + & + & + & - & + & GC \\
\hline & L64 & + & + & + & + & + & + & GC \\
\hline & L92 & + & - & + & + & - & - & GC \\
\hline & L48 & - & + & + & - & + & + & GC \\
\hline & L66 & + & + & + & - & + & + & GC \\
\hline & L95 & + & + & + & - & + & - & GC \\
\hline & L102 & + & - & - & + & - & - & GC \\
\hline & L91 & - & + & - & + & - & - & GC \\
\hline & L105 & + & - & + & - & - & + & GC \\
\hline & L83 & - & + & + & - & + & - & GC \\
\hline & L51 & + & + & + & - & + & - & GC \\
\hline & L72 & + & + & + & + & - & - & GC \\
\hline & L79 & + & + & + & + & - & - & GC \\
\hline & L78 & - & + & - & + & - & + & GC \\
\hline & L61 & - & + & - & + & - & - & GC \\
\hline & L49 & + & + & - & + & - & - & GC \\
\hline & L70 & + & - & + & + & - & + & GC \\
\hline & L100 & + & + & + & + & - & + & GC \\
\hline & L99 & + & + & + & - & - & + & GC \\
\hline & L98 & + & + & + & - & - & + & GC \\
\hline & L89 & - & + & - & + & - & - & GC \\
\hline & L69 & - & + & - & + & - & - & GC \\
\hline \multirow[t]{17}{*}{ SV40-negative cases } & L20 & + & - & - & - & + & + & Non-GC \\
\hline & L02 & - & + & - & + & + & - & Non-GC \\
\hline & L12 & - & + & - & + & + & - & Non-GC \\
\hline & L28 & + & + & - & + & + & - & Non-GC \\
\hline & L38 & - & + & - & + & + & - & Non-GC \\
\hline & L26 & - & + & - & + & + & - & Non-GC \\
\hline & $\mathrm{L} 17$ & + & - & - & - & + & - & Non-GC \\
\hline & L09 & - & - & - & - & + & - & Non-GC \\
\hline & L04 & - & + & - & + & + & - & Non-GC \\
\hline & L01 & - & - & - & + & + & - & Non-GC \\
\hline & L08 & - & + & - & + & + & - & Non-GC \\
\hline & L25 & - & - & - & + & + & - & Non-GC \\
\hline & $\mathrm{L} 27$ & + & + & - & - & + & - & Non-GC \\
\hline & L10 & + & + & - & - & + & - & Non-GC \\
\hline & L11 & - & - & - & - & + & - & Non-GC \\
\hline & L33 & - & + & - & + & + & + & Non-GC \\
\hline & L13 & + & + & + & + & + & + & GC \\
\hline
\end{tabular}


Table 3 Continued

\begin{tabular}{|c|c|c|c|c|c|c|c|c|}
\hline \multirow[t]{2}{*}{ SV40 status } & \multirow[t]{2}{*}{ Case no. } & \multicolumn{5}{|c|}{ Immunohistochemistry } & \multirow[t]{2}{*}{ PCR BCL2/JH } & \multirow[t]{2}{*}{ Germinal center status } \\
\hline & & P53 & $B C L 2$ & CD10 & $B C L 6$ & MUM1 & & \\
\hline & $\mathrm{L} 40$ & - & + & + & + & - & - & GC \\
\hline & L24 & - & - & + & + & - & - & GC \\
\hline & L22 & - & - & + & - & + & + & GC \\
\hline & L30 & + & - & + & - & + & - & GC \\
\hline & L18 & + & + & + & - & - & - & GC \\
\hline & L11 & + & + & + & - & - & - & GC \\
\hline & L05 & + & - & + & - & + & - & GC \\
\hline & L36 & - & + & + & - & + & - & GC \\
\hline & L29 & + & - & - & + & - & - & GC \\
\hline & L39 & - & + & - & + & - & - & GC \\
\hline & L07 & - & - & - & + & - & - & GC \\
\hline & L35 & + & - & + & - & - & - & GC \\
\hline & L19 & - & - & + & - & + & - & GC \\
\hline & L03 & - & - & + & - & + & - & GC \\
\hline & L32 & - & - & + & - & + & - & GC \\
\hline & L31 & + & + & - & + & - & - & GC \\
\hline & L15 & + & + & - & + & - & - & GC \\
\hline & L23 & - & + & - & + & - & - & GC \\
\hline & L06 & - & + & + & + & - & + & GC \\
\hline & L41 & - & + & + & - & - & - & GC \\
\hline & $\mathrm{L} 37$ & - & - & - & + & - & - & GC \\
\hline
\end{tabular}

${ }^{\mathrm{a}}$ Germinal center (GC) status was determined based on the immunoexpression profile of CD10, BCL6, and MUM1 as described in the Materials and methods section.

Table 4 Comparison of clinicopathological and immunohistochemical findings, and SV40 status in diffuse large B-cell lymphomas according to the germinal center status

\begin{tabular}{|c|c|c|c|}
\hline \multirow[t]{2}{*}{ Characteristics } & \multicolumn{2}{|c|}{ Germinal center status } & \multirow[t]{2}{*}{$\mathrm{P}$-value } \\
\hline & $\begin{array}{l}\text { Germinal center } \\
\text { phenotype } \\
(\mathrm{n}=61)\end{array}$ & $\begin{array}{c}\text { Non-germinal } \\
\text { center phenotype } \\
(\mathrm{n}=25)\end{array}$ & \\
\hline \multicolumn{4}{|l|}{ Gender } \\
\hline Male & 34 & 14 & 0.567 \\
\hline Female & 27 & 11 & \\
\hline \multicolumn{4}{|c|}{ Age at diagnosis (year) } \\
\hline $\begin{array}{l}\text { Median } \\
\text { (range) }\end{array}$ & $61(3-85)$ & $65(18-82)$ & 0.911 \\
\hline \multicolumn{4}{|l|}{ Tumor location } \\
\hline Nodal & 41 & 19 & 0.420 \\
\hline Extranodal & 20 & 6 & \\
\hline \multicolumn{4}{|c|}{ BCL2 immunodetection } \\
\hline Positive & 41 & 15 & 0.524 \\
\hline Negative & 20 & 10 & \\
\hline \multicolumn{4}{|c|}{ P53 immunodetection } \\
\hline Positive & 33 & 14 & 0.872 \\
\hline Negative & 28 & 11 & \\
\hline \multicolumn{4}{|l|}{ SV40 status } \\
\hline Positive & 39 & 9 & 0.018 \\
\hline Negative & 22 & 16 & \\
\hline
\end{tabular}

${ }^{\mathrm{a}}$ Bold number indicates significant correlation $(P<0.05)$.

in SV40-positive than in SV40-negative diffuse large B-cell lymphoma cases $(21 / 48$ (44\%) vs $5 / 38$ (13\%); $P=0.002$; Table 6).
Table 5 Immunoexpression of CD10, BCL6, MUM1, BCL2, and P53 in SV40-positive and SV40-negative diffuse large B-cell lymphoma cases

\begin{tabular}{|c|c|c|c|}
\hline & $\begin{array}{l}\text { Number of SV40- } \\
\text { positive cases } \\
(\mathrm{n}=48)\end{array}$ & $\begin{array}{c}\text { Number of SV40- } \\
\text { negative cases } \\
(\mathrm{n}=38)\end{array}$ & P-value \\
\hline \multicolumn{4}{|l|}{ CD10 } \\
\hline Negative & 21 & 23 & 0.122 \\
\hline Positive & 27 & 15 & \\
\hline \multicolumn{4}{|l|}{ BCL6 } \\
\hline Negative & 19 & 17 & 0.63 \\
\hline Positive & 29 & 21 & \\
\hline \multicolumn{4}{|l|}{ MUM1 } \\
\hline Negative & 26 & 14 & 0.111 \\
\hline Positive & 22 & 24 & \\
\hline \multicolumn{4}{|l|}{ BCL2 } \\
\hline Negative & 14 & 17 & 0.135 \\
\hline Positive & 34 & 21 & \\
\hline \multicolumn{4}{|l|}{ P53 } \\
\hline Negative & 15 & 24 & 0.003 \\
\hline Positive & 33 & 14 & \\
\hline
\end{tabular}

SV40, simian virus 40 .

${ }^{\mathrm{a}}$ Bold number indicates significant correlation $(P<0.05)$.

To determine the independent factors correlating with SV40 association, we have performed a multivariate analysis including variables that are found to be associated with SV40 in univariate analyses. Multivariate analysis revealed that germinal center phenotype, $\mathrm{t}(14 ; 18)$ translocation, and P53 nuclear accumulation remain independently 

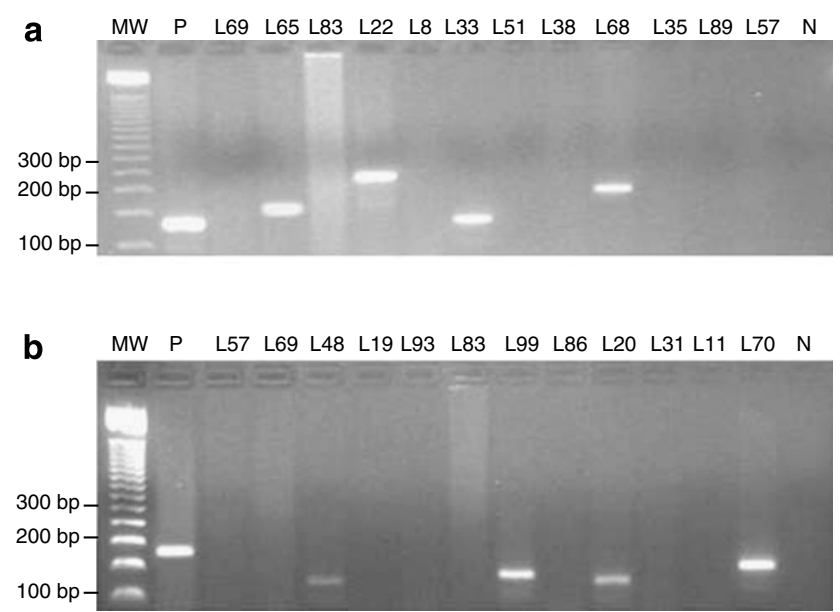

Figure 3 Representative examples of the detection of BCL2/JH rearrangements by PCR in diffuse large B-cell lymphomas from Tunisia. (a) Ethidium bromide-stained agarose gel electrophoresis for $\mathrm{t}(14 ; 18)$ detection using primers $\mathrm{MBR} / \mathrm{JH}$ targeting the major breakpoint cluster region; Lanes L65, L22, L33, and L68 represent samples that are positive for the translocation. Lanes L69, L83, L8, L51, L38, L35, L89, and L57 represent negative samples for the translocation. (b) Ethidium bromide-stained agarose gel electrophoresis for $\mathrm{t}(14 ; 18)$ detection using primers ICR/JH targeting the ICR. Lanes L70, L99, L48, and L20 represent samples that are positive for the translocation. Lanes L69, L11, L72, and L51 represent negative samples for the translocation. Lanes MW show 50 bp DNA ladder (Promega); lanes $\mathrm{P}$ and $\mathrm{N}$ represent positive control (DNA isolated from human follicular lymphomas sample) and negative control (without DNA template), respectively.

associated with SV40 presence in diffuse large B-cell lymphomas (Table 7).

\section{Survival Analyses}

To investigate the prognostic significance of clinicopathological features and the presence of SV40 DNA in diffuse large B-cell lymphomas, survival analyses were performed. Univariate analyses using the Kaplan-Meier method showed that patients with low International Prognosis Index scores have a better survival than those with high International Prognosis Index scores $(P<0.0001$; Figure 4a). Similarly, when we divided patients according to germinal center status, the germinal center group showed a better survival rate than the non-germinal center group ( $P=0.006$; Figure $4 \mathrm{~b})$. Moreover, using a multivariate Cox proportional hazards regression analysis, both germinal center status and International Prognosis Index scores were shown to be independent prognostic factors in the prediction of outcome $(P=0.001$ and $<0.0001$, respectively; Table 8). However, BCL2 and P53 expression, and $\mathrm{t}(14 ; 18)$ translocation status did not show any significant impact on overall survival (Figure 4c-e). Also, no significant correlation was found between the SV40 status and overall survival $(P=0.641$; Figure $4 \mathrm{f})$. When we considered either the germinal center status or the International Prognosis Index score, the impact of SV40 on overall survival appeared to be complex. In fact, among patients with low International Prognosis Index scores, no significant correlation was found between overall survival and SV40 status $(P=0.998$; Figure $5 \mathrm{c})$. In contrast, among patients with high International Prognosis Index scores, the SV40-positive subgroup showed better survival rates than the SV40-negative subgroup $(P=0.035 ;$ Figure $5 \mathrm{~d})$. Interestingly, among patients with germinal center phenotype, the presence of SV40 DNA was significantly associated with shorter survival (40.3 vs 22.5 months; $P=0.034$ ) (Figure 5a). However, among patients with non-germinal center phenotype, the presence of SV40 DNA seemed to be associated with better survival $(P=0.084$; Figure $5 \mathrm{~b})$.

\section{Discussion}

Diffuse large B-cell lymphomas are characterized by heterogeneous biological, clinical, immunophenotypic, and genetic features. ${ }^{1,2}$ In recent years, knowledge about diffuse large B-cell lymphomas has increased considerably in light of repeated findings of germinal and non-germinal center groups using gene expression profiles. ${ }^{8,37-40}$ This has made it possible to study new risk factors in more biologically distinct subgroups of diffuse large B-cell lymphomas. However, gene expression profiles are difficult to incorporate in routine diagnosis and the preferred approach would be to supplant gene expression profiling with immunohistochemistry to identify the same groups. This approach was applied by several investigators who showed that conventional immunohistochemistry could give similar results concerning prognosis using protein expression patterns for a small number of selected markers. $^{6-9}$

In this study, we present the first comprehensive, clinical, immunohistochemical, and biological study of a series of diffuse large B-cell lymphomas in an African country, making special reference to prognostic factors and markers that have been reported to define biological subgroups of diffuse large B-cell lymphomas. Thus, the results reported here can be considered representative regarding epidemiological as well as clinical features. Interestingly, using the decision-tree proposed by Hans et $a l,{ }^{6} 71 \%$ of diffuse large B-cell lymphoma cases showed a germinal center phenotype. This proportion of patients with diffuse large B-cell lymphomas from Tunisia (an area with intermediary risk for nonHodgkin's lymphomas) is somewhat higher than described in previous studies from Europe and the United States, ranging from 35 to $52 \% .^{6,7,9,41}$ The much higher rate of diffuse large B-cell lymphomas with germinal center phenotype in our patients as compared with Western populations contrasts with the low frequency of follicular lymphomas in 
Tunisia (less than $10 \%$ of non-Hodgkin's lymphomas $^{5}$ ) and argues for differences in the relative importance of etiologic factors such as viral infections

Table 6 Comparison of clinicopathological and immunohistochemical findings, and SV40 status in diffuse large B-cell lymphomas according to the $\mathrm{t}(14 ; 18)$ translocation status

\begin{tabular}{|c|c|c|c|}
\hline \multirow[t]{2}{*}{ Characteristics } & \multicolumn{2}{|c|}{$t(14 ; 18)$} & \multirow[t]{2}{*}{$\mathrm{P}$-value ${ }^{\mathrm{a}}$} \\
\hline & $\begin{array}{l}\text { Number of } \\
\text { positive cases } \\
(\mathrm{n}=26)\end{array}$ & $\begin{array}{l}\text { Number of } \\
\text { negative cases } \\
(\mathrm{n}=60)\end{array}$ & \\
\hline \multicolumn{4}{|l|}{ Gender } \\
\hline Male & 16 & 32 & 0.482 \\
\hline Female & 10 & 28 & \\
\hline \multicolumn{4}{|c|}{ Age at diagnosis (year) } \\
\hline $\begin{array}{l}\text { Median } \\
\text { (range) }\end{array}$ & $56(3-83)$ & $64(5-85)$ & 0.545 \\
\hline \multicolumn{4}{|l|}{ Tumor location } \\
\hline Nodal & 17 & 43 & 0.560 \\
\hline Extranodal & 9 & 17 & \\
\hline \multicolumn{4}{|c|}{ BCL2 immunodetection } \\
\hline Positive & 20 & 36 & 0.130 \\
\hline Negative & 6 & 24 & \\
\hline \multicolumn{4}{|c|}{ P53 immunodetection } \\
\hline Positive & 18 & 29 & 0.115 \\
\hline Negative & 8 & 31 & \\
\hline \multicolumn{4}{|c|}{ Germinal center status } \\
\hline $\begin{array}{l}\text { Germinal } \\
\text { center }\end{array}$ & 21 & 40 & 0.186 \\
\hline $\begin{array}{l}\text { Non-germinal } \\
\text { center }\end{array}$ & 5 & 20 & \\
\hline \multicolumn{4}{|l|}{ SV40 status } \\
\hline Positive & 21 & 27 & 0.002 \\
\hline Negative & 5 & 33 & \\
\hline
\end{tabular}

GC, germinal center; SV40, simian virus 40 .

${ }^{a}$ Bold number indicates significant correlation $(P<0.05)$. and/or genetic susceptibilities between different populations.

Although clinical follow-up was available for a limited number of our patients, we confirmed previous reports showing that patients with germinal center phenotype have a significantly better outcome than patients with non-germinal center phenotype..$^{8,37-40}$ Our findings also validate the prognostic interest of the predictive model proposed by Hans et $a l^{6}$ to subclassify diffuse large B-cell lymphomas into germinal center and non-germinal center groups. Moreover, to assess whether germinal center status could be used as an independent complement to the International Prognosis Index scores according to this predictive model, we performed a multivariate analysis and our results revealed that the germinal center status is an independent marker for prognosis in patients with diffuse large B-cell lymphomas. Furthermore, in the current study we found that the germinal center phenotype was more frequently associated with SV40-positive diffuse large B-cell lymphomas than SV40-negative cases $(P=0.018$; Table 4$)$. These data confirm previous results reported by Vilchez et $a l,{ }^{42}$ who found that germinal center immunophenotype was more frequently associated with SV40-positive diffuse large B-cell lymphomas in human immunodeficiency virus-positive patients.

The current study is the first to investigate the impact of SV40 on survival in patients with diffuse large B-cell lymphomas. When all cases were considered, no significant difference in cumulative survival rates regarding the SV40 status was seen (Figure 4f). Interestingly, when we have taken into consideration either the International Prognosis Index score or the germinal center status, a complex impact of SV40 on overall survival was noted. Indeed, in the germinal center diffuse large B-cell lymphoma group, SV40-positive cases have a

Table 7 Multivariate logistic regression analysis of germinal center status, the t(14;18) translocation, and P53 accumulation associated with SV40 in diffuse large B-cell lymphomas

\begin{tabular}{|c|c|c|c|c|c|}
\hline \multirow[t]{2}{*}{ Characteristics } & \multicolumn{2}{|c|}{ SV40 status } & \multicolumn{3}{|c|}{ Multivariate analysis } \\
\hline & $\begin{array}{l}\text { Number of positive } \\
\text { cases }(\mathrm{n}=48)\end{array}$ & $\begin{array}{c}\text { Number of negative } \\
\text { cases }(\mathrm{n}=38)\end{array}$ & Odds ratio & $\begin{array}{l}95 \% \text { confidence } \\
\text { interval }\end{array}$ & $\mathrm{P}$-value \\
\hline \multicolumn{6}{|c|}{ Germinal center status } \\
\hline $\begin{array}{l}\text { Germinal center } \\
\text { phenotype }\end{array}$ & 39 & 22 & 3425 & $1.132-10.189$ & 0.029 \\
\hline $\begin{array}{l}\text { Non-germinal } \\
\text { center phenotype }\end{array}$ & 9 & 16 & & & \\
\hline \multicolumn{6}{|l|}{$t(14 ; 18)$} \\
\hline Positive & 20 & 6 & 2859 & $1.350-13.839$ & 0.014 \\
\hline Negative & 28 & 32 & & & \\
\hline \multicolumn{6}{|l|}{ P53 immunodetection } \\
\hline Positive & 33 & 14 & 4485 & $1.494-10.958$ & 0.006 \\
\hline Negative & 15 & 24 & & & \\
\hline
\end{tabular}

SV40, simian virus 40 .

${ }^{a}$ Bold number indicates significant correlation $(P<0.05)$. 

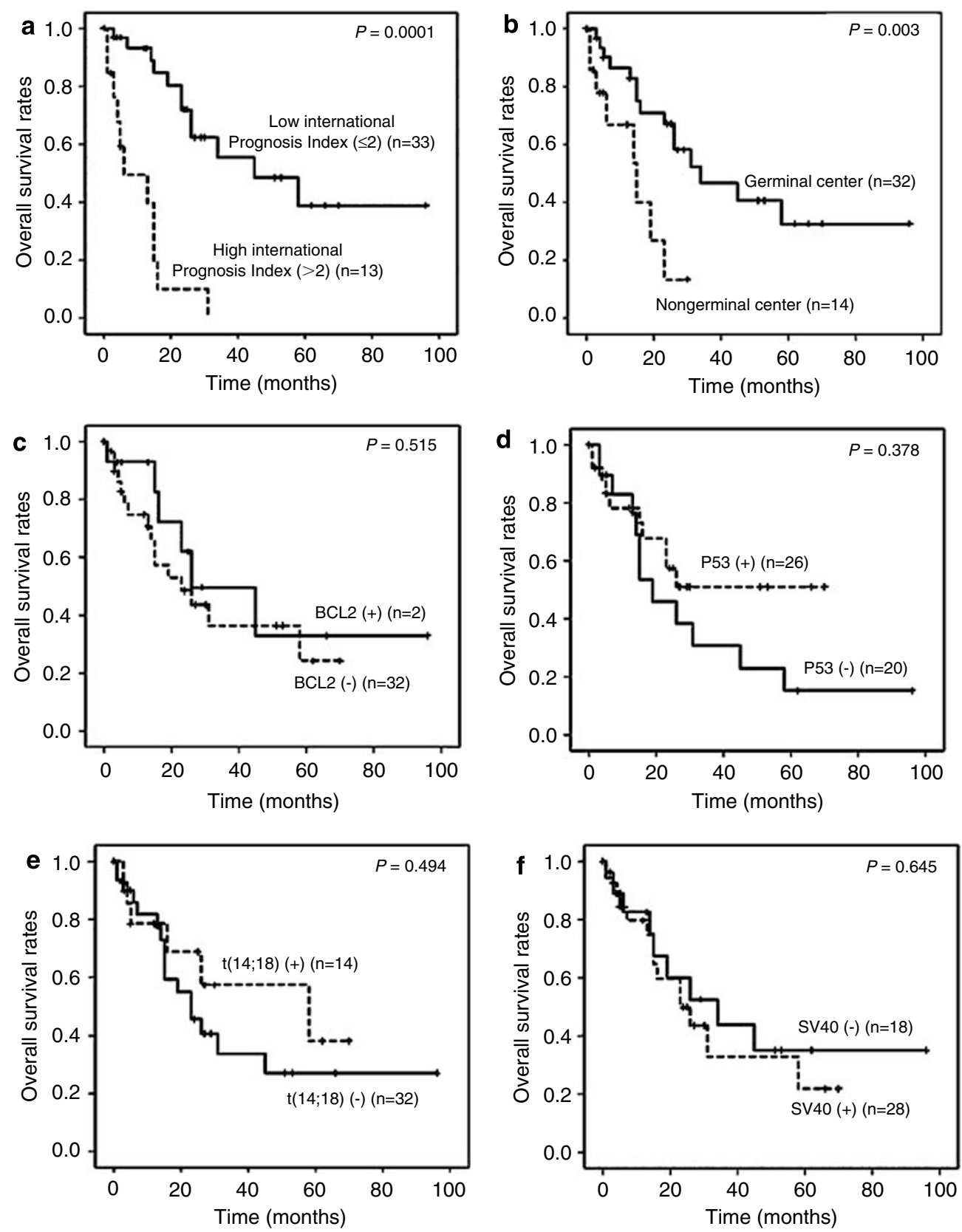

Figure 4 Kaplan-Meier analyses of overall survival for Tunisian patients with diffuse large B-cell lymphomas according to the International Prognostic Index (a), the germinal center status (b), BCL2 (c) and P53 (d) expression, t(14;18) translocation presence (e), and SV40 status (f). Survival curves show that high International Prognostic Index scores and non-germinal center phenotype are correlated with shorter survival $(P=0.0001$ and 0.006 , respectively). However, BCL2 and P53 expression, $\mathrm{t}(14 ; 18)$ translocation, and SV40 status have no impact on overall survival.

Table 8 Multivariate Cox proportional hazards regression analysis for prognostic factors affecting overall survival in diffuse large B-cell lymphomas in Tunisian patients

\begin{tabular}{llrr}
\hline Variables & Unfavorable factor & Odds ratio & $\begin{array}{c}\text { 95\% Confidence } \\
\text { interval }\end{array}$ \\
\hline Germinal center status & Non-germinal center phenotype & 6.340 & $\begin{array}{c}2.178-18.455 \\
4.309-33.680\end{array}$ \\
International Prognosis Index score & High scores $(>2)$ & 12.047 & $\mathbf{0 . 0 0 1}$ \\
& & $\mathbf{0 . 0 0 0 1}$
\end{tabular}

${ }^{\mathrm{a} B o l d}$ number indicates significant correlation $(P<0.05)$. 

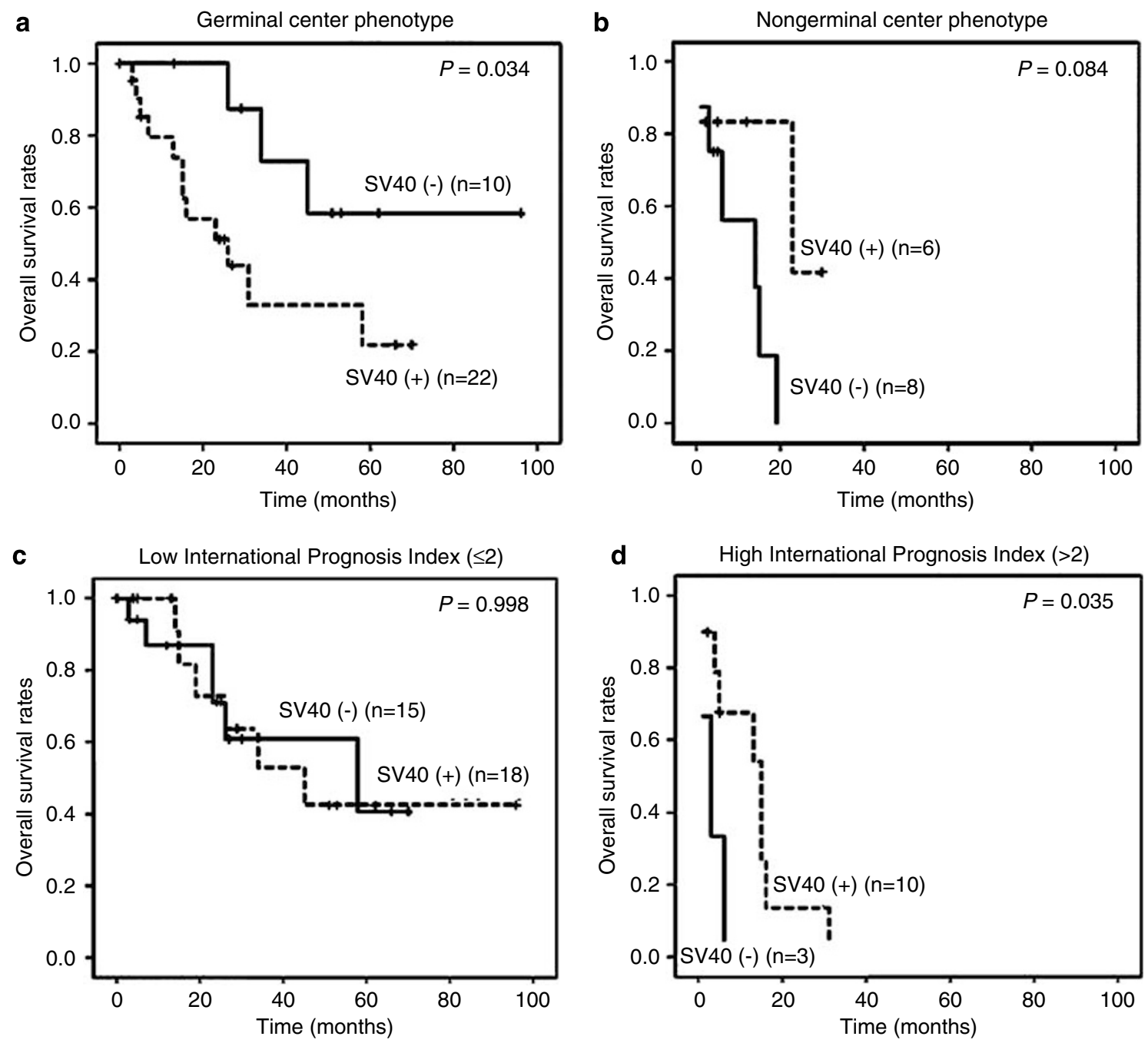

Figure 5 Kaplan-Meier analyses of overall survival for Tunisian patients with diffuse large B-cell lymphomas according to the SV40 status in the germinal center group (a), non-germinal center group (b), low International Prognostic Index score group (c), and high International Prognostic Index score group (d). Survival curves show that among patients with the germinal center phenotype, the presence of SV40 correlates with poorer overall survival $(P=0.041)$. However, among patients with high International Prognostic Index scores, the presence of SV40 correlates with better overall survival $(P=0.035)$.

shorter survival rate than SV40-negative cases (Figure 5a). Conversely, among patients with high International Prognosis Index scores, the SV40 presence correlates with better survival (Figure 5d). This complex pattern of SV40 implication in diffuse large B-cell lymphomas may be in relation to the impact of this virus on the methylation of several tumor suppressor genes as shown previously by our group. ${ }^{27}$

On the other hand, the $t(14 ; 18)$ translocation, which is a characteristic of follicular lymphoma and a proportion of diffuse large B-cell lymphomas, is considered to be an important initiating event in lymphomagenesis. ${ }^{43,44}$ The frequency of the $t(14 ; 18)$ in diffuse large B-cell lymphomas showed wide geographic variation, and has been linked to the germinal center phenotype in several studies. . $^{6,8,38,45,46}$ However, it is still unknown what role this translocation plays in their pathogenesis. ${ }^{45,46}$ To our knowledge, the current study is the first to investigate the prevalence of this translocation in diffuse large B-cell lymphomas in a North African country. We found, by three PCR-based methods, evidence of $t(14 ; 18)$ in $30 \%$ of the cases investigated, a frequency in the range of that reported previously in diffuse large B-cell lymphomas (10-40\%). ${ }^{10}$ In the present study, no correlation between $\mathrm{t}(14 ; 18)$ and germinal center phenotype was observed. This result is also in agreement with previous reports. ${ }^{45,47}$ On the other hand, the prognostic significance of $\mathrm{t}(14 ; 18)$ in diffuse large B-cell lymphomas is also controversial; some studies have shown no effect on survival, ${ }^{10,45,46,48-50}$ whereas others have found an increased incidence of relapse, ${ }^{47,51}$ decreased responsiveness to therapy, shorter survival,,$^{52,53}$ or a correlation with extensive disease. ${ }^{54}$ In the current study, we found no significant difference in clinical outcome between cases with and without $t(14 ; 18)$ translocation. 
The $t(14 ; 18)$ translocation is thought to induce an overexpression of BCL2 protein, but BCL2 protein expression in diffuse large B-cell lymphomas is not dependent on the presence of BCL2 translocation. ${ }^{10,51,55,56}$ This observation was also noted in our series. Overall, $65 \%$ of our cases expressed BCL2 protein, a rate falling into the range of previous reports $(34-69 \%) .{ }^{10,50,52}$ In this study, we found that BCL2 was expressed in $67 \%$ of the germinal center group and in $60 \%$ of the nongerminal center group. Previous studies have also found no difference in the expression of BCL2 protein between germinal center and non-germinal center diffuse large B-cell lymphoma groups. ${ }^{8,57}$ In fact, they reported expression of BCL2 in $50-67 \%$ of germinal center and $45-62 \%$ of non-germinal center diffuse large B-cell lymphomas. BCL2 expression has been shown to be an adverse prognostic factor in previous reports, alone or in conjunction with other factors. ${ }^{6,9,54,57}$ Indeed, many previous studies have found no significant difference in overall survival regarding the expression of BCL2. ${ }^{10,52}$ Similarly, in the present study, BCL2 protein expression had no prognostic effect on overall survival even within the germinal center group, as shown by other investiga- tors. $^{9,57}$ In contrast, other studies have found a shorter time to relapse in patients with high BCL2 expression and consequently have found it to be more important for event-free survival than overall survival. ${ }^{10,48}$

It is well known that BCL2/JH gene rearrangements occur at the pre-B-cell stage. ${ }^{5}$ This suggests that the stage of cells that undergo chromosomal translocation and the stage of resulting lymphomas are different. ${ }^{45,52}$ However, BCL2 gene alterations did not give a sufficient growth signal for cells to proliferate because it is known that only cells in the germinal center have an important proliferating capacity. ${ }^{45,55}$ Cells harboring the $\mathrm{t}(14 ; 18)$ translocation could be thus upregulated by the accumulation of secondary multiple alterations, such as viral infections. ${ }^{30,45}$ Interestingly, in this study, we have shown a high frequency of $t(14 ; 18)$ translocation in SV40-positive diffuse large B-cell lymphomas. These observations suggest that the SV40 infection may 'accelerate' the tumoral transformation of $\mathrm{B}$ cells, mainly those harboring the $\mathrm{t}(14 ; 18)$ translocation. They also could, in part, explain the high frequency of diffuse large B-cell lymphomas without pre-existing follicular lymphomas in our country,
Peripheral blood, lymphoid or non-lymphoid tissues
Nodal or extra-nodal lymphoid tissues

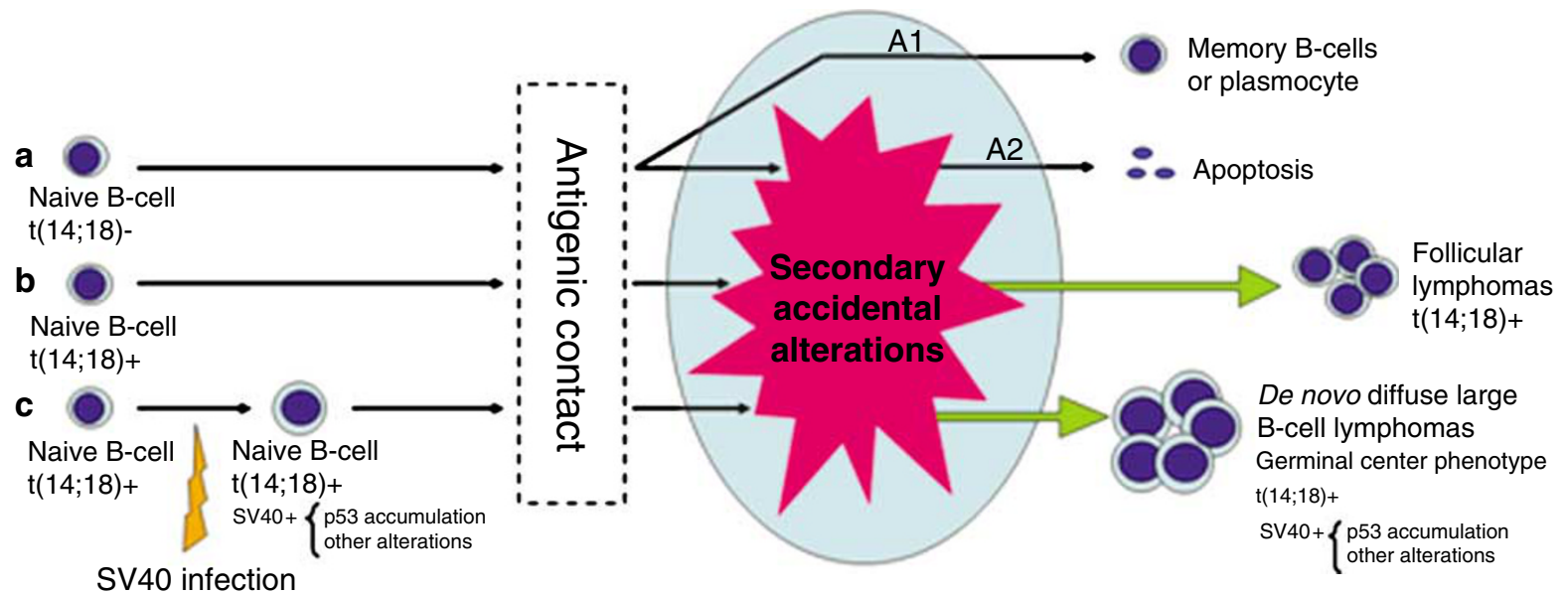

Germinal Center

(Intensive proliferation)

Figure 6 A model for the pathogenetic events leading to the development of SV40-associated diffuse large B-cell lymphomas. (a) Under normal conditions, the antigen-stimulated naive B cells migrate to the germinal center, proliferate, and undergo somatic mutations, leading to generate plasma cells and memory B cells (A1). ${ }^{61}$ During this process, BCL2 expression at the follicular center is downregulated, and cells with low affinity of the antibody or showing abnormalities die as a result of apoptosis (A2). ${ }^{61}$ (b) t(14;18) translocation occurs as a rare random event in the early stage of B-cell development, during immunoglobulin gene rearrangement. ${ }^{55}$ The aberrant BCL2 expression resulting from this translocation protects the cell and its progeny from apoptosis and accumulating abnormalities, resulting in a growth advantage for these cells at the follicular center stage. ${ }^{62}$ Repeated cycles of proliferation from subsequent antigenic encounters expand this clone and result in additional genetic abnormalities, leading progressively to the development of follicular lymphoma ${ }^{62}$ (c) During passage in tissues believed to establish a latent SV40 infection (like kidney or central nervous system), B cells harboring the $\mathrm{t}(14 ; 18)$ could be infected by the SV40. At this stage, infected B cells accumulate a number of genetic and/or epigenetic alterations, which alone were not enough for cells to become malignant. After antigenic contact, such B cells will have more chance to be blocked at the germinal center stage of differentiation and will be not able to undergo apoptosis because of simultaneous antiapoptotic effects of BCL2 overexpression (as a result of $\mathrm{t}(14 ; 18)$ translocation) and SV40-induced cell cycle alterations (including inactivation of P53 protein), resulting in a growth advantage for these cells and leading to the development of de novo diffuse large B-cell lymphomas. 
and particularly the high frequency of diffuse large B-cell lymphomas with germinal center phenotype in the current series. Further studies are needed to confirm these constatations.

The $P 53$ gene is affected in a wide range of human cancers, including lymphomas. ${ }^{11,56,58}$ Mutations of the P53 gene often lead to the accumulation of the mutated protein in the nucleus of neoplastic cells. ${ }^{11}$ However, overexpression of wild type of the P53 has been previously described in a significant proportion of diffuse large B-cell lymphomas, and the occurrence of positive immunostaining does not reflect point mutations in the P53 gene and vice versa. ${ }^{12-14,58}$ The discordance between protein overexpression and the absence of mutations in diffuse large B-cell lymphomas has suggested the existence of other mechanisms to stabilize the P53 protein, such as binding of P53 protein to viral proteins. ${ }^{14,58}$ It has been shown in vitro that SV40 large $\mathrm{T}$ antigen has the ability to interact with and functionally inactivate the P53 protein. In the present study, a significant correlation between P53 accumulation and the presence of SV40 in diffuse large B-cell lymphomas was found (Table 5). Similar results have been also demonstrated by Carbone et $a l^{16}$ and Zhen et $a l^{17}$ in human mesotheliomas and brain tumors, respectively. This observation suggests a functional role of SV40 in the inactivation of P53 in human diffuse large B-cell lymphomas. Demonstration of the presence of both SV40 T antigen and P53 protein in the nuclei of the same neoplastic cells could support this hypothesis. However, the feasibility of such an approach is at present limited by several technical factors, especially the lack of dependable commercial tools for morphological detection of SV40 that could allow reproducible results. ${ }^{17,59,60}$

Taken together, these data and the fact that P53 nuclear accumulation, germinal center phenotype, and the presence of $t(14 ; 18)$ translocation were correlated independently with the presence of SV40 DNA in diffuse large B-cell lymphomas in our series (Table 7) led us to propose a model in which we summarize the presumable scenario of the pathogenetic events in SV40-associated diffuse large B-cell lymphomas (Figure 6). According to this model, SV40 infection likely occurs during passage of B cells in peripheral tissues believed to establish a latent SV40 infection, such as in the kidney or central nervous system. Infected cells harboring $t(14 ; 18)$ translocation and with expression of BCL2 have more chance to escape apoptosis and survive. At this stage, those infected B cells initiate accumulation of several alterations, due to the effect of SV40 $\mathrm{T}$ antigen, including P53 inactivation. After antigenic contact, such B cells will have more chance to be blocked at the germinal center stage of differentiation and to escape apoptosis because of simultaneous antiapoptotic effects of BCL2 overexpression (as a result of $\mathrm{t}(14 ; 18)$ translocation) and SV40-induced cell cycle control alterations, including inactivation of P53 protein. Further studies are needed to confirm this hypothesis.

In summary, this is the first report that documents the immunophenotype profile and the prevalence of $t(14 ; 18)$ in diffuse large B-cell lymphomas in a North African country. Interestingly, we found that the majority $(71 \%)$ of diffuse large B-cell lymphoma cases in Tunisia belong to the germinal center group. In addition, the germinal center phenotype, $\mathrm{t}(14 ; 18)$, and P53 accumulation correlate with the presence of SV40. Furthermore, among patients with germinal center phenotype, the presence of SV40 was associated with worse survival rate. These observations support the hypothesis that SV40 may have a role in the pathogenesis of diffuse large B-cell lymphomas and could thus lead to new diagnostic, therapeutic, and preventive approaches.

\section{References}

1 Leoncini L, Delsol G, Gascoyne RD, et al. Aggressive B-cell lymphomas: a review based on the workshop of the XI Meeting of the European Association for Haematopathology. Histopathology 2005;46:241-255.

2 Jaffe ES, Harris NL, Stein H, Vardiman JW (eds). World Health Organization Classification of Tumours. Pathology and Genetics of Tumours of the Haematopoietic and Lymphoid Tissues. IARC Press: Lyon, 2001, pp 171-174.

3 Pileri SA, Dirnhofer S, Went P, et al. Diffuse large B-cell lymphoma: one or more entities? Present controversies and possible tools for its subclassification. Histopathology 2002;41:482-509.

4 de Leval L, Harris NL. Variability in immunophenotype in diffuse large B-cell lymphoma and its clinical relevance. Histopathology 2003;43:509-528.

5 Amara K, Trimeche M, Ziadi S, et al. PCR-based clonality analysis of B-cell lymphomas in paraffinembedded tissues: diagnostic value of immunoglobulin kappa and lambda light chain gene rearrangement investigation. Pathol Res Pract 2006;202:425-431.

6 Hans CP, Weisenburger DD, Greiner TC, et al. Confirmation of the molecular classification of diffuse large B-cell lymphoma by immunohistochemistry using a tissue microarray. Blood 2003;103:275-282.

7 Chang CC, McClintock S, Cleveland RP, et al. Immunohistochemical expression patterns of germinal center and activation B-cell markers correlate with prognosis in diffuse large B-cell lymphoma. Am J Surg Pathol 2004;28:464-470.

8 Colomo L, Lopez-Guillermo A, Perales M, et al. Clinical impact of the differentiation profile assessed by immunophenotyping in patients with diffuse large B-cell lymphoma. Blood 2003;101:78-84.

9 Berglund M, Thunberg U, Amini RM, et al. Evaluation of immunophenotype in diffuse large B-cell lymphoma and its impact on prognosis. Mod Pathol 2005;18: 1113-1120.

10 Hill ME, MacLennan KA, Cunningham DC, et al. Prognostic significance of BCL-2 expression and bcl-2 major breakpoint rearrangement in diffuse large cell non-Hodgkin's lymphoma: a British national lymphoma investigation study. Blood 1996;88:1046-1051. 
11 Imamura J, Miyoshi I, Koeffler HP. P53 in hematologic malignancies. Blood 1994;84:2412-2421.

12 Villuendas R, Piris MA, Algara P, et al. The expression of p53 protein in non-Hodgkin's lymphomas is not always dependent on p53 gene mutations. Blood 1993; 82:3151.

13 Martinez-Delgado B, Rbledo M, Arranz F, et al. Correlation between mutations in the p53 gene and protein expression in human lymphomas. Am J Hematol 1997;55:1-8.

14 Oka T, sarker AB, Teramoto N, et al. p53 expression in non-Hodgkin's lymphomas is infrequently related to the p53 gene mutations. Pathol Int 1998;48:15-21.

15 Villuendas R, Pires MA, Orradre JL, et al. P53 expression in lymphomas and reactive lymphoid tissue. J Pathol 1992;166:235-241.

16 Carbone M, Rizzo P, Grimley PM, et al. Simian virus-40 large-T antigen binds p53 in human mesotheliomas. Nat Med 1997;3:908-912.

17 Zhen HN, Zhang X, Bu HY, et al. Expression of the simian virus 40 large tumor antigen and formation of Tag-p53 and Tag-pRb complexes in human brain tumors. Cancer 1999;86:2124-2132.

18 Klumb CE, Hassan R, Zalcberg IR, et al. P53 protein expression does not correlate with EBV status in childhood B non-Hodgkin lymphomas. Pediatr Blood Cancer 2004;43:115-119.

19 Iamaroon A, Pongsiriwet S, Mahanupab P, et al. Oral non-Hodgkin lymphomas: studies of EBV and p53 expression. Oral Dis 2003;9:14-18.

20 Edwards RH, Raab-Traub N. Alterations of the p53 gene in Epstein-Barr virus-associated immunodeficiency-related lymphomas. J Virol 1994;68:1309-1315.

21 Vilchez RA, Madden CR, Kozinetz CA, et al. Association between simian virus 40 and non-Hodgkin lymphoma. Lancet 2002;359:817-823.

22 Shivapurkar N, Harada K, Reddy J, et al. Presence of simian virus 40 DNA sequences in human lymphomas. Lancet 2002;359:851-852.

23 Shivapurkar N, Takahashi T, Reddy J, et al. Presence of simian virus 40 DNA sequences in human lymphoid and hematopoietic malignancies and their relationship to aberrant promoter methylation of multiple genes. Cancer Res 2004;64:3757-3760.

24 Nakatsuka S, Liu A, Dong Z, et al. Osaka Lymphoma Study Group. Simian virus 40 sequences in malignant lymphomas in Japan. Cancer Res 2003;63:7606-7608.

25 Meneses A, Lopez-Terrada D, Zanwar P, et al. Lymphoproliferative disorders in Costa Rica and simian virus 40. Haematologica 2005;90:1635-1642.

26 Chen PM, Yen CC, Yang MH, et al. High prevalence of SV40 infection in patients with nodal non-Hodgkin's lymphoma but not acute leukemia independent of contaminated polio vaccines in Taiwan. Cancer Invest 2006;24:223-228.

27 Amara K, Trimeche M, Ziadi S, et al. Presence of simian virus 40 DNA sequences in diffuse large B-cell lymphomas in Tunisia correlates with aberrant promoter hypermethylation of multiple tumor suppressor genes. Int J Cancer 2007;121:2693-2702.

28 Butel JS, Lednicky JA. Cell and molecular biology of simian virus 40: implications for human infections and disease. J Natl Cancer Inst 1999;91:119-134.

29 Engels EA. Does simian virus 40 cause non-Hodgkin lymphoma? A review of the laboratory and epidemiological evidence. Cancer Invest 2005;23:529-536.

30 Peh SC, Shaminie J, Tai YC, et al. The pattern and frequency of $\mathrm{t}(14 ; 18)$ translocation and immuno- phenotype in Asian follicular lymphoma. Histopathology 2004;45:501-510.

31 Visco C, Canal F, Parolini C, et al. The impact of P53 and P21waf1 expression on the survival of patients with the germinal center phenotype of diffuse large B-cell lymphoma. Haematologica 2006;91:687-690.

32 Hermine O, Haioun C, Lepage E, et al. Prognostic significance of bcl-2 protein expression in aggressive non-Hodgkin's lymphoma. Groupe d'Etude des Lymphomes de l'Adulte (GELA). Blood 1996;87:265-272.

33 Man Y, Moinfar F, Bratthauer GL, et al. An improved method for DNA extraction from paraffin sections. Pathol Res Pract 2001;197:635-642.

34 Gomez M, Wu X, Wang YL. Detection of BCL2-IGH using single-round PCR assays. Diagn Mol Pathol 2005;14:17-22.

35 Albinger-Hegyi A, Hochreutener B, Abdou MT, et al. High frequency of $t(14 ; 18)$-translocation breakpoints outside of major breakpoint and minor cluster regions in follicular lymphoma. Am J Pathol 2002;160: 823-832.

36 Batstone PJ, Goodlad JR. Efficacy of screening the intermediate cluster region of the bcl2 gene in follicular lymphomas by PCR. J Clin Pathol 2005; 58:81-82.

37 Alizadeh AA, Eisen MB, Davis RE, et al. Distinct types of diffuse large B-cell lymphoma identified by gene expression profiling. Nature 2000;403:503-511.

38 Rosenwald A, Wright G, Chan WC, et al. The use of molecular profiling to predict survival after chemotherapy for diffuse large-B-cell lymphoma. N Engl J Med 2002;346:1937-1947.

39 Lossos LS, Czerwinski DK, Alizadeh AA, et al. Prediction of survival in diffuse large-B-cell lymphoma based on the expression of six genes. N Engl J Med 2004;350:1828-1837.

40 Shipp MA, Ross KN, Tamayo P, et al. Diffuse large B-cell lymphoma outcome prediction by gene-expression profiling and supervised machine learning. Nat Med 2002;8:68-74.

41 Barbanti-Brodano G, Sabbioni S, Martini F, et al. Simian virus 40 infection in human and association with human diseases: results and hypotheses. Virology 2004;318:1-9.

42 Vilchez RA, Lopez-Terrada D, Middleton JR, et al. Simian virus 40 tumor antigen expression and immunophenotypic profile of AIDS-related non-Hodgkin's lymphoma. Virology 2005;342:38-46.

43 Weiss LM, Warnke RA, Sklar J, et al. Molecular analysis of the $t(14 ; 18)$ chromosomal translocation in malignant lymphomas. N Engl J Med 1987;317: 1185-1189.

44 Tsujimoto Y, Cossman J, Jaffe E, et al. Involvement of the bcl-2 gene in human follicular lymphoma. Science 1985;228:1440-1443.

45 Huang JZ, Sanger WG, Greiner TC, et al. The t(14;18) defines a unique subset of diffuse large B-cell lymphoma with a germinal center B-cell expression profile. Blood 2002;99:2285-2290.

46 Iqbal J, Sanger WG, Horsman DE, et al. BCL2 translocation defines a unique tumor subset within the germinal center B-cell-like diffuse large B-cell lymphoma. Am J Pathol 2004;165:159-166.

47 Barrans SL, Evans PAS, O'Connor SJM, et al. The $t(14 ; 18)$ is associated with germinal center-derived diffuse large B-cell lymphoma and is a strong predictor of outcome. Clin Cancer Res 2003;9:2133-2139. 
48 Gascoyne RD, Adomat SA, Krajewski S, et al. Prognostic significance of Bcl-2 protein expression and Bcl-2 gene rearrangement in diffuse aggressive nonHodgkin's lymphoma. Blood 1997;90:244-251.

49 Martinka M, Comeau T, Foyle A, et al. Prognostic significance of $t(14 ; 18)$ and bcl-2 gene expression in follicular small cleaved cell lymphoma and diffuse large cell lymphoma. Clin Invest Med 1997;20: $364-370$.

$50 \mathrm{Xu}$ Y, McKenna RW, Doolittle JE, et al. The t(14;18) in diffuse large B-cell lymphoma: correlation with germinal center-associated markers and clinical features. Appl Immunohistochem Mol Morphol 2005;13: 116-123.

51 Jacobson JO, Wilkes BM, Kwaiatkowski DJ, et al. Bcl-2 rearrangements in de novo diffuse large cell lymphoma. Association with distinctive clinical features. Cancer 1993;72:231-236.

52 Tang SC, Visser L, Hepperle B, et al. Clinical significance of bcl-2-MBR gene rearrangement and protein expression in diffuse large-cell non-Hodgkin's lymphoma: an analysis of 83 cases. J Clin Oncol 1994;12:149-154.

53 Yunis JJ, Mayer MG, Arnesen MA, et al. bcl-2 and other genomic alterations in the prognosis of large-cell lymphoma. N Engl J Med 1989;320:1047-1054.

54 Kramer MH, Hermans J, Wijburg E, et al. Clinical relevance of BCL2, BCL6, and MYC rearrangements in diffuse large B-cell lymphoma. Blood 1998;92: 3152-3162.

55 Seto M. Molecular mechanisms of lymphomagenesis through transcriptional disregulation by chromosomal translocation. Int J Hematol 2002;76:323-326.

56 Soini Y, Paakko P, Alavaikko M, et al. p53 expression in lymphatic malignancies. J Clin Pathol 1992;45: 1011-1014.

57 Barrans SL, Carter I, Owen RG, et al. Germinal center phenotype and bcl-2 expression combined with the International Prognostic Index improves patient risk stratification in diffuse large B-cell lymphoma. Blood 2002;99:1136-1143.

58 Sanchez-Beato M, Sanchez-Aguilera A, Piris MA. Cell cycle deregulation in B-cell lymphomas. Blood 2003;101: 1220-1235.

59 Pilatte Y, Vivo C, Renier A, et al. Absence of SV40 large T-antigen expression in human mesothelioma cell lines. Am J Respir Cell Mol Biol 2000;23:788-793.

60 Simsir A, Fetsch P, Bedrossian CWM, et al. Absence of SV-40 large T antigen (Tag) in malignant mesothelioma effusions: an immunocytochemical study. Diagn Cytopathol 2001;25:203-207.

61 Kuppers R. Mechanisms of B-cell lymphoma pathogenesis. Nat Rev 2005;5:251-262.

62 Kuppers R, Klein U, Hansmann ML, et al. Cellular origin of human B-cell lymphomas. N Engl J Med 1999;341:1520-1529. 